\title{
Activity, stability and kinetic parameters for $\alpha$-chymotrypsin catalysed reactions in AOT/isooctane reverse micelles with nonionic and zwitterionic mixed surfactants
}

\author{
SANTOSH KUMAR VERMA ${ }^{\mathrm{a}, *}$ and KALLOL K GHOSH ${ }^{\mathrm{b}}$ \\ ${ }^{a}$ Shri Shankaracharya Institute of Technology and Management, Bhilai 490 020, India \\ ${ }^{b}$ School of Studies in Chemistry, Pt. Ravishankar Shukla University, Raipur 492 010, India \\ e-mail: vermasantosh08@gmail.com
}

MS received 23 April 2012; revised 2 October 2012; accepted 5 November 2012

\begin{abstract}
Reverse micelles (RMs) of sodium 1,4-bis(2-ethylhexyl)sulphosuccinate (AOT) in nonpolar organic solvents are widely known to have very high solubilization power for water. The method is applied to the hydrolysis of $p$-nitrophenyl acetate (PNPA) catalysed by $\alpha$-chymotrypsin $(\alpha-\mathrm{CT})$ in AOT/isooctane/buffer RMs. The increase in $\alpha$-CT activity and stability was an optimum at $\mathrm{w}_{o}\left(\left[\mathrm{H}_{2} \mathrm{O}\right] /[\mathrm{AOT}]\right)=10, \mathrm{z}$ [Isooctane $] /[\mathrm{AOT}])=5$. Three typical surfactants were selected based on their head group charges: a non-ionic surfactant Triton-X 100 and two zwitterionic sulphobetaine surfactants of the type $\mathrm{C}_{n} \mathrm{H}_{2 n+1} \mathrm{~N}^{+} \mathrm{Me}_{2}\left(\mathrm{CH}_{2}\right)_{3} \mathrm{SO}_{3}^{-}$ $\left(\mathrm{n}=10\right.$; SB3-10, $\mathrm{n}=16$; SB3-16). The kinetic parameters (such as $k_{\mathrm{cat}}$ and $\left.K_{\mathrm{M}}\right)$ of the $\alpha-\mathrm{CT}$ at $27^{\circ} \mathrm{C}$ were determined and compared in the absence and presence of three surfactants. The effect of chain length of zwitterionic surfactant (SB3-10 and SB3-16) on the enzymatic efficacy of $\alpha$-CT as a function of mixed surfactant addition has been investigated in AOT/isooctane RMs at $\mathrm{pH} 7.75$.
\end{abstract}

Keywords. $\quad \alpha$-Chymotrypsin; stability; $p$-nitrophenyl acetate; zwitterionic surfactants; reverse micelles

\section{Introduction}

Reverse micelles (RMs) are attractive hosts for enzyme catalysed reactions because they solubilize both hydrophobic and hydrophilic parts of surfactants in single microscopically isotropic phase. ${ }^{1-5}$ Fundamental studies on stability, catalytic behaviour and physicochemical factors are essential for the efficient applications of enzymes in RMs. The micellar binding of the substrate in reaction media governs the hydrolytic reaction rate. ${ }^{6-10} \mathrm{RMs}$ have attracted a significant interest over the years because of their tremendous application in colloid science. RMs containing enzymes have been thought of as microreactors in which the enzymes can be sheltered and protected from the effects of solvents. ${ }^{11-13}$ The nature and the concentration of the surfactant play a significant role in the kinetics of reactions catalysed by enzymes in RM solutions. A great deal of efforts have been made to investigate the lipases and $\alpha$-chymotrypsin $(\alpha$-CT) catalysed hydrolytic reactions. ${ }^{14,15}$

*For correspondence
Most of the studies involving enzyme catalysis in microemulsions have been performed by using sodium 1,4-bis(2-ethylhexyl)sulphosuccinate (AOT), a wellcharacterized anionic surfactant that forms spherical RMs and has considered as a model system for micellar enzymology. ${ }^{16-20}$ RMs formed by AOT are very stable over a wide range of concentrations in the absence of co-surfactants. Although, lot of work has been carried out to develop the activity and stability of enzymes in AOT RM with cationic and nonionic surfactants but still, little information is available for the study of $\alpha$ CT in RM of zwitterionic surfactants. ${ }^{21}$ A few investigations in the area of reversed micellar enzymology 22,23 have implied the importance of the local molar concentrations of water and other ions on the activities of water-pool encapsulated hydrophilic enzymes.

Recently, we performed a systematic study for catalytic activity of $\alpha$-CT on the attack at $\mathrm{C}=\mathrm{O}$ centre of carboxylate ester $p$-nitrophenyl acetate (PNPA) in oilin-water microemulsions. ${ }^{24}$ It was observed that $k_{\text {cat }}$ and $K_{\mathrm{M}}$ values were influenced as a function of chain length of the oil. On the other hand, catalytic activity of $\alpha$-CT was also explored in organic cosolvents ${ }^{25}$ and various cationic surfactants. ${ }^{26,27}$ Effect of surfactant concentration, head group dimensions and chain length 
on the catalytic efficiency of $\alpha$-CT was studied in detail. The extensive analysis of our previous investigations give an insight into the mechanism of micellar enzymology.

The catalytic effect of enzyme was monitored in RMs under the effect of nonionic and zwitterionic surfactants to obtain an in depth knowledge of enzymatic reaction in micellar media. We propose the advances in catalytic activity of $\alpha$-CT with various degrees of hydration to varying AOT concentration and its stability in RM medium. The hydrolysis of PNPA catalysed by $\alpha$-CT in AOT/isooctane/buffer RM using non-ionic surfactant Triton-X 100 and two zwitterionic sulphobetaine surfactants of the type $\mathrm{C}_{\mathrm{n}} \mathrm{H}_{2 \mathrm{n}+1} \mathrm{~N}^{+} \mathrm{Me}_{2}\left(\mathrm{CH}_{2}\right)_{3} \mathrm{SO}_{3}^{-}(\mathrm{n}=$ 10; SB3-10, $\mathrm{n}=16$; SB3-16) was studied at $\mathrm{pH} 7.75$ (scheme 1). A comparative study was also carried out in the RM of AOT and zwitterionic surfactants (SB310 and SB3-16), using $\alpha-C$ T. Effect of mixed surfactant systems on enzymatic activity of $\alpha$-CT has been discussed. RMs are thermodynamically stable amphipathic molecules that consist of a water pool surrounded by a surfactant layer, with the hydrophobic moieties of the surfactant molecules interacting with the bulk hydrophobic solvent as shown in figure 1 .

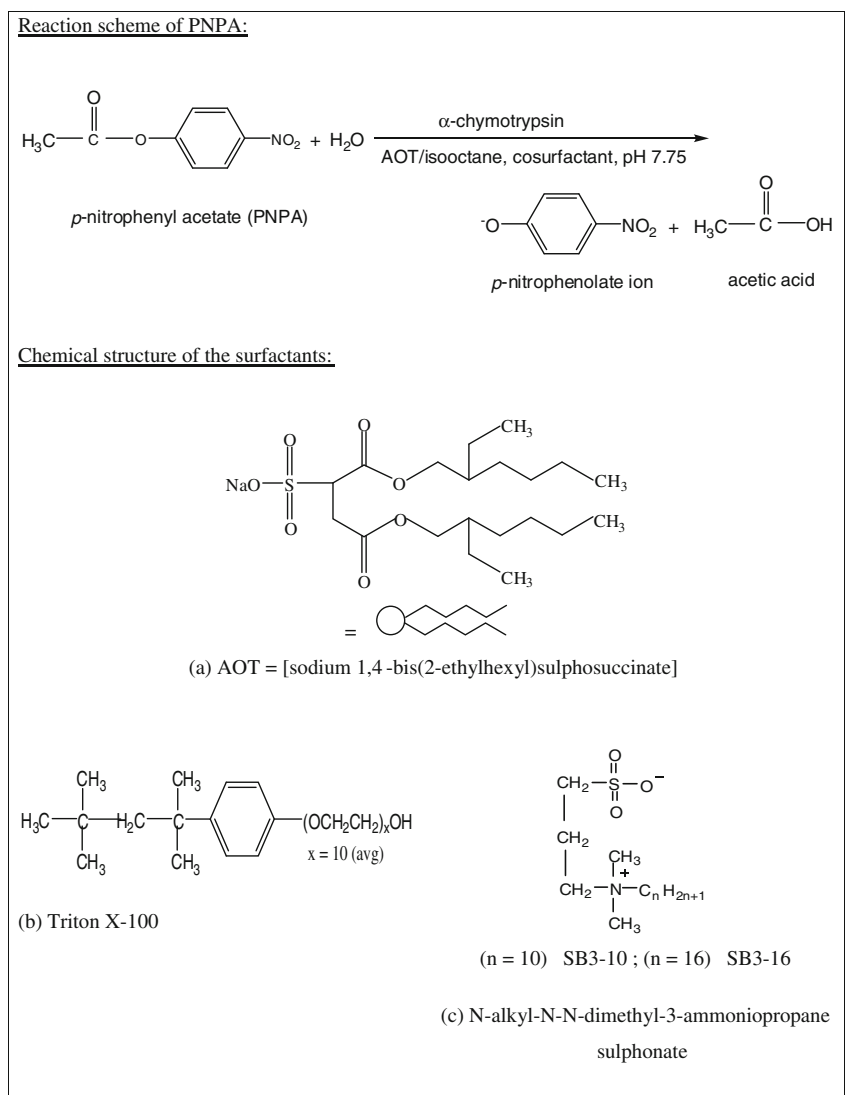

Scheme 1. $\alpha$-CT catalysed hydrolysis of PNPA in the presence of surfactants at $\mathrm{pH} 7.75$.

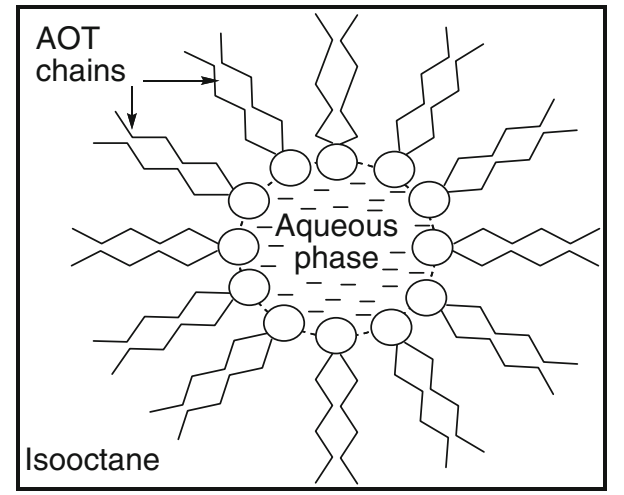

Figure 1. Schematic representation of AOT/isooctane reverse micelles.

\section{Experimental}

\subsection{Materials}

$\alpha$-CT (EC 3.4.21.1; type-II from bovine pancreas, molecular weight $25 \mathrm{kDa}$, isoelectric point $\mathrm{p} I$ 8.8), surfactant i.e., Triton-X 100, N-alkyl-N,N-dimethyl-3ammoniopropane sulphonate (SB3-10 and SB3-16), and Trizma base was procured from Sigma and used without further purification. The substrate, PNPA was obtained from Fluka (Steinheim, Switzerland). Tris(hydroxymethyl)aminomethane (Tris) ( $p \mathrm{Ka} \mathrm{8.3),} \mathrm{HCl}$ and organic solvents (ethanol and isooctane) were procured from Qualigens Fine Chemicals (Mumbai, India).

\subsection{Solution preparation}

Enzyme and substrate solutions were freshly prepared in the appropriate buffer immediately before their use in the experiments. Buffer $\mathrm{pH}$ was fixed at 7.75 using $0.1 \mathrm{M}$ hydrochloric acid. The $\alpha$-CT solution was freshly prepared in acetate buffer $\mathrm{pH}=4.6\left(0.1 \mathrm{M} \mathrm{CH}_{3} \mathrm{COOH}\right.$ and $0.1 \mathrm{M} \mathrm{CH}_{3} \mathrm{COONa}$ ). To improve solubility of substrate, the PNPA was prepared in pure ethanol. Stock solutions of AOT RMs containing Tris/ $\mathrm{HCl}$ buffer in isooctane were varied from 0 to $25 \mathrm{mM}$ (for different water pool size fixed within the range, $\mathrm{w}_{\mathrm{o}}=5$ to 20) and further at fixed AOT concentration (0 to $25 \mathrm{mM}), \mathrm{w}_{\mathrm{o}}$ values were varied within the range 0 to 20. All the RM solutions were stirred for 10 to $14 \mathrm{~h}$ using the 2 MLH stirrer bar and finally the solutions became clear at room temperature. For the study of mixed surfactants (SB3-10 or SB3-16 or TX-100) addition, the AOT concentration was selected as $15 \mathrm{mM}$ $\left(\mathrm{w}_{\mathrm{o}}=10\right)$. 


\subsection{Spectra}

All the spectral measurements were performed using a Varian Cary 50 UV-visible spectrophotometer equipped with Peltier Temperature controller unit at $27^{\circ} \mathrm{C}$. The hydrolytic activity of $\alpha$-CT towards PNPA was monitored by following the increase in the absorbance at $400 \mathrm{~nm}$ due to the formation of $p$-nitrophenolate ion $\left(\mathrm{PNP}^{-}\right)$at $\mathrm{pH}$ 7.75. For all the kinetic runs, varying concentration of PNPA and $\alpha$-CT were maintained at 0.065 to $0.52 \mathrm{mM}$ and $13 \mu \mathrm{M}$, respectively. The product extinction coefficient was $12000 \mathrm{M}^{-1} \mathrm{~cm}^{-1}$.

\subsection{Activity measurements}

$\alpha$-CT activity was measured using PNPA at different concentration of AOT in isooctane and buffer RM solution. In brief, $3 \mathrm{~mL}$ of total reaction mixture contained enzyme, substrate and RM solution at $\mathrm{pH}$ 7.75. The required amount of substrate (range 50 to $400 \mu \mathrm{L}$ or 0.065 to $0.52 \mathrm{mM}$ of PNPA from stock solution $7.3 \mathrm{mg}$ of PNPA in $10 \mathrm{~mL}$ of ethanol) was added in aliquot and then $20 \mu \mathrm{L}(13 \mu \mathrm{M}, 0.33 \mathrm{mg} / \mathrm{mL})$ of $\alpha$-CT solution was added. After $5 \mathrm{~min}$ of incubation, the reaction was stopped by the addition of $0.5 \mathrm{~mL}$ of $2 \%$ Trizma base. The absorbance of the clear transparent solution was measured at $400 \mathrm{~nm}$. One unit (U) of $\alpha$-CT activity was defined as the amount of enzyme that released $1 \mu \mathrm{M}$ of $\mathrm{PNP}^{-} / \mathrm{min}$ under the above conditions. The study of stability of AOT/isooctane RMs and its activity towards the enzymatic hydrolysis of PNPA was carried out in stoppered test tube. Aliquots of the reaction mixture were withdrawn at selected time intervals and measured initial reaction rate, $V_{0}$, for PNPA hydrolysis by $\alpha$-CT using spectrophotometric procedure as described elsewhere. At appropriate time intervals, $3 \mathrm{~mL}$ of each $\mathrm{RM}$ was mixed and the reaction was followed at temperature $27^{\circ} \mathrm{C}$. The final $\alpha$-CT and PNPA concentrations were $13 \mu \mathrm{M}$ and $0.13 \mathrm{mM}$, respectively at water-surfactant ratio, $\mathrm{w}_{\mathrm{o}}=10$.

\subsection{Measurements of enzyme kinetics}

The initial reaction rate, $V_{0}$, was determined from the slope of the $\mathrm{PNP}^{-}$concentration versus time profiles using enzyme kinetics software (Varian). The rates of all enzyme-catalysed reactions were corrected for the rate of spontaneous non-enzymatic hydrolysis (AOT/isooctane) determined under identical conditions. All the data points obey to Michaelis-Menten kinetics. Kinetic parameters $k_{\text {cat }}$ and $K_{\mathrm{M}}$ in all RM solution were obtained by the linear regression analysis of Lineweaver-Burk plot (eq. 1).

$$
[\alpha-\mathrm{CT}] / V_{0}=1 /\left(\mathrm{k}_{\mathrm{cat}}\right)+\left(K_{\mathrm{M}} / k_{\mathrm{cat}}\right)[\mathrm{PNPA}]^{-1}
$$

\section{Results and discussion}

\subsection{Activity studies of $\alpha-C T$}

$\alpha$-CT shows different kinetic behaviour depending on substrate concentration which determined their physical and chemical state. During first 5 min of reaction the absorbance versus time plots were obtained at various concentrations of PNPA and initial velocity, $V_{0}$ were calculated accordingly (figure 2). The activity of $\alpha$-CT at different PNPA concentration within the range 0.065 to $0.39 \mathrm{mM}$ was investigated. The enzymatic activity $(\mathrm{U} / \mathrm{mL})$ was found to increase and graph obtained was hyperbolic in nature. At lower PNPA concentration $(0.065 \mathrm{mM}) 70 \mathrm{U} / \mathrm{mL}$ of $\alpha$-CT activity was noted which further raised to $275 \mathrm{U} / \mathrm{mL}$ at $0.39 \mathrm{mM}$ of PNPA concentration.

\subsection{Enzymatic reaction in AOT/buffer/isooctane RMs}

The kinetic studies were performed to investigate the hydrolysis of PNPA catalysed by $\alpha$-CT in AOT/buffer/isooctane RMs and the results are summarized in table 1 . Representative plots obtained for $V_{\mathrm{o}} /[\alpha$ $\mathrm{CT}$ ] versus [PNPA] to varying concentrations of AOT at $\mathrm{w}_{\mathrm{o}}=10$ are shown in figure 3. Data of figure 3

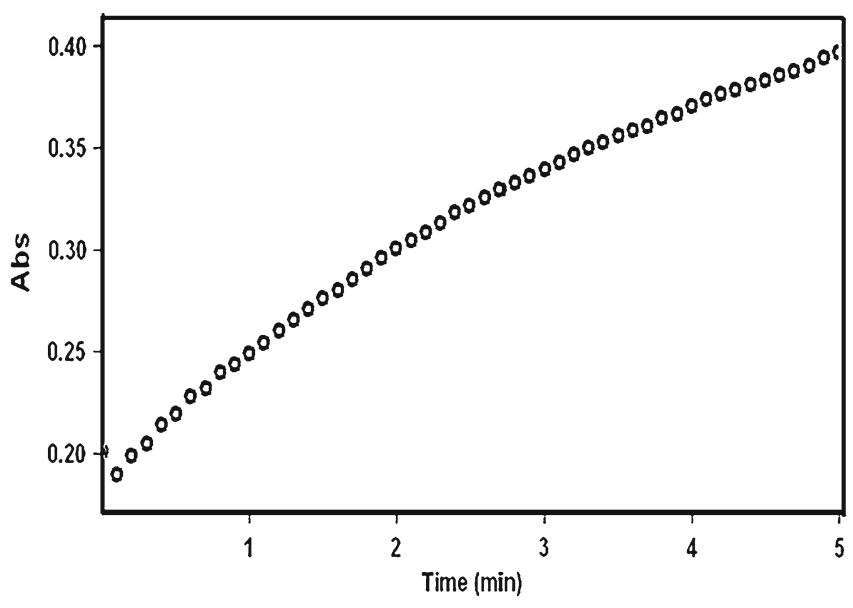

Figure 2. UV-vis absorption spectra of absorbance versus time plot for the hydrolysis of $0.13 \mathrm{mM}$ PNPA by $\alpha$-CT in AOT/isooctane RM. [AOT] $=25 \mathrm{mM}, \mathrm{w}_{\mathrm{o}}=10, \mathrm{pH} 7.75$, Temp. $=27^{\circ} \mathrm{C}$. 
Table 1. Summary of the kinetic experimental data for $\alpha$-chymotrypsin catalysed hydrolysis of PNPA in AOT/isooctane/buffer system.

\begin{tabular}{lcccc}
\hline $\mathrm{w}_{\mathrm{o}}$ & AOT $(\mathrm{mM})$ & $10^{2} k_{\text {cat }}\left(\mathrm{s}^{-1}\right)$ & $10^{3} K_{\mathrm{M}}(\mathrm{M})$ & $k_{\mathrm{cat}} / K_{\mathrm{M}}\left(\mathrm{M}^{-1} \mathrm{~s}^{-1}\right)$ \\
\hline 5 & 5 & $6.16 \pm 0.55$ & $0.70 \pm 0.08$ & 88.0 \\
& 15 & $5.12 \pm 0.80$ & $0.75 \pm 0.20$ & 68.3 \\
& 25 & $4.64 \pm 0.38$ & $0.82 \pm 0.10$ & 56.5 \\
10 & 5 & $10.1 \pm 2.23$ & $0.70 \pm 0.10$ & 144 \\
& 15 & $7.19 \pm 1.48$ & $1.05 \pm 0.03$ & 68.4 \\
& 25 & $4.64 \pm 0.51$ & $1.40 \pm 0.04$ & 33.1 \\
20 & 5 & $2.40 \pm 0.30$ & $0.50 \pm 0.20$ & 48.0 \\
& 15 & $1.52 \pm 0.23$ & $0.55 \pm 0.06$ & 27.6 \\
& 25 & $1.49 \pm 0.12$ & $0.70 \pm 0.10$ & 21.2 \\
\hline
\end{tabular}

$[\alpha-\mathrm{CT}]=13 \mu \mathrm{M},[$ Tris $/ \mathrm{HCl}$ buffer $]=10 \mathrm{mM}$, Temp. $=27^{\circ} \mathrm{C}, \mathrm{pH}=7.75$, $[\mathrm{PNPA}]=(0.065$ to 0.52$) \mathrm{mM}$

indicate that, the profiles are strongly dependent on the AOT concentration. A notable decrease in reaction rate was observed with an increase in the AOT concentration. The linear trend of graph accounts for MichaelisMenten kinetics where the concentration of the substrate is in large excess over the enzyme concentration (figure 4).

According to the pioneering work of Neuman et al. ${ }^{28}$ a trace amount of water has a very significant on the aggregation behaviour of sodium bis(2ethylhexyl)phosphate (NaDEHP) and to understand the behaviour of surfactants in apolar solvents, such as the critical micelle concentration $(\mathrm{cmc})$ or the growth of RMs. Similarly Aguilar et al. ${ }^{29}$ pointed out that the catalytic rate constant $k_{\text {cat }}$ in the micellar solutions was independent of [AOT] but slightly decreased with an increase in water content, $\mathrm{w}_{\mathrm{o}}$. In

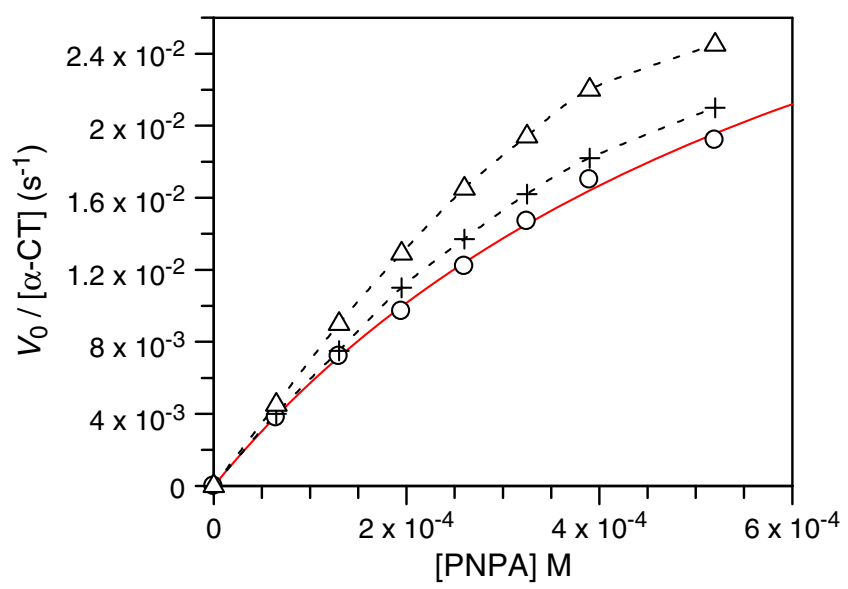

Figure 3. Effect of AOT concentration on the hydrolysis of PNPA in reverse micellar solution at $\mathrm{w}_{\mathrm{o}}=10 .[\alpha-\mathrm{CT}]=$ $13 \mu \mathrm{M}$, [Tris/ $\mathrm{HCl}$ buffer $]=10 \mathrm{mM}$, Temp. $=27^{\circ} \mathrm{C}, \mathrm{pH}=$ $7.75,[\mathrm{PNPA}]=(0.065-0.52) \mathrm{mM} .(\Delta) \mathrm{AOT}=5 \mathrm{mM} ;(+)$ $\mathrm{AOT}=15 \mathrm{mM}$; (०) AOT $=25 \mathrm{mM}$. the present investigation, the $\alpha$-CT catalysed hydrolysis of PNPA in AOT/isooctane/buffer RMs, the carbonyl carbon is attacked by activated serine hydroxide ion of $\alpha$-CT. The rate at which the reaction proceeds is strongly influenced by the surrounding of the ester bond (i.e., the presence of electron-withdrawing or -releasing groups or bulky substituents exerting steric hindrance).

The most remarkable observation of the kinetic studies show that there was an increment in the values of Michaelis constant, $K_{\mathrm{M}}$ by 1.17 -fold for $\mathrm{w}_{\mathrm{o}}=5(0.70$ to 0.82$) \mathrm{M}, 2.0$-fold for $\mathrm{w}_{\mathrm{o}}=10(0.70$ to 1.40$) \mathrm{M}$ and 1.40 -fold for $\mathrm{w}_{\mathrm{o}}=20(0.50$ to 0.70$) 10^{-3} \mathrm{M}$. A simultaneous decrease in catalytic constant, $k_{\text {cat }}$ by a factor of

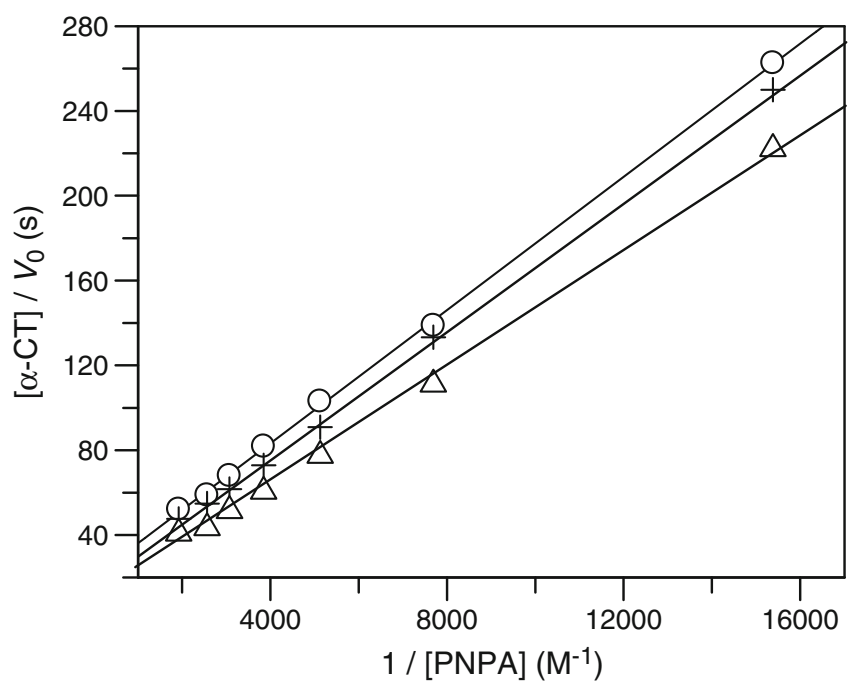

Figure 4. Effect of AOT concentration on the LineweaverBurk plot for the $\alpha$-chymotrypsin catalysed hydrolysis of PNPA in AOT/isooctane reverse micelles at $\mathrm{w}_{\mathrm{o}}=10$. $[\alpha-$ $\mathrm{CT}]=13 \mu \mathrm{M}$, [Tris/ $\mathrm{HCl}$ buffer $]=10 \mathrm{mM}$, Temp. $=27^{\circ} \mathrm{C}$, $\mathrm{pH}=7.75$, $[\mathrm{PNPA}]=(0.065-0.52) \mathrm{mM} .(\Delta) \mathrm{AOT}=5 \mathrm{mM}$; (+) $\mathrm{AOT}=15 \mathrm{mM}$; (o) $\mathrm{AOT}=25 \mathrm{mM}$. 
1.32 for $\mathrm{w}_{\mathrm{o}}=5$ (6.16 to 4.64) $10^{-2} \mathrm{~s}^{-1}, 2.17$ for $\mathrm{w}_{\mathrm{o}}=$ $10(10.1$ to 4.64$) 10^{-2} \mathrm{~s}^{-1}$ and 1.61 for $\mathrm{w}_{\mathrm{o}}=20(2.40$ to 1.49$) 10^{-2} \mathrm{~s}^{-1}$ was noted. Incorporation of substrate into the micellar pseudophase explains the increase in $K_{\mathrm{M}}$ observed at higher surfactant concentrations. $K_{\mathrm{M}}$ increases with AOT concentration probably as a result of the distribution of the substrate between the micelles and the external solvent. The catalytic activities are dependent on the water pool size of the micelles, i.e. on the $\mathrm{w}_{\mathrm{o}}$ parameter consequently the optimal sized micelles allow the achievement of maximal $k_{\text {cat }}$ in an average value. The lower values of the $K_{\mathrm{M}}$ indicate that the $\alpha$-CT and PNPA are tightly bound and form the enzyme substrate complex more easily in RM solutions. This trend of enzymatic activity of $\alpha$-CT is quiet similar to that of our previous investigations in microemulsion (ME) systems. ${ }^{24}$ It was reported that in different ME systems reactivity of enzyme was higher at low water content $\left(\mathrm{w}_{\mathrm{o}}\right)$.

\subsection{Stability of $\alpha-C T$ in AOT/isooctane RMs}

The operational stability of enzyme is essential for a successful application of bioconversions in microemulsions. Studies regarding stability of $\alpha$-CT in MEs have been carried out in our previous work but, the stability was measured against water content. However, in the present investigations enzyme stability was checked against time in reverse micellar solutions. The enzyme $(\alpha-\mathrm{CT})$ was stable up to $24 \mathrm{~h}$ and further decrease in stability was observed with time.

Effect of various parameters on the stability of $\alpha$ $\mathrm{CT}$ in RMs has been studied such as water content, $\mathrm{pH}$ of aqueous microphase, temperature and additives. Table 2 summarizes the results for the stability of $\alpha$ $\mathrm{CT}$ in AOT/isooctane RM. The uniform increase in initial velocity was observed up to $24 \mathrm{~h}$ which further

Table 2. Time stability showing the initial velocity $\left(V_{\mathrm{o}}\right)$ of $\alpha$-CT catalysed hydrolysis of PNPA $(0.13 \mathrm{mM})$ at varying AOT concentration, $\mathrm{w}_{\mathrm{o}}=10$, reversed micelles in isooctane at $\mathrm{pH} 7.75$.

\begin{tabular}{lccc}
\hline \multirow{2}{*}{$\begin{array}{l}\text { Time after } \\
\text { preparation }\end{array}$} & \multicolumn{3}{c}{$V_{\mathrm{o}} \pm 0.02 \mu \mathrm{mol} / \mathrm{s}$} \\
\cline { 2 - 4 } & $5 \mathrm{mM} \mathrm{AOT}$ & $15 \mathrm{mM} \mathrm{AOT}$ & $25 \mathrm{mM} \mathrm{AOT}$ \\
\hline $5 \mathrm{~min}$ & 0.087 & 0.093 & 0.071 \\
$30 \mathrm{~min}$ & 0.104 & 0.108 & 0.078 \\
$1 \mathrm{~h}$ & 0.118 & 0.113 & 0.072 \\
$24 \mathrm{~h}$ & 0.117 & 0.119 & 0.085 \\
$48 \mathrm{~h}$ & 0.113 & 0.101 & 0.070 \\
1 week & 0.108 & 0.092 & 0.067 \\
2 weeks & 0.051 & 0.040 & 0.023 \\
\hline
\end{tabular}

decreased to approximately 43\% (5 mM AOT), 33\% (15 mM AOT), and $27 \%$ (25 mM AOT) of maximal activity. The stability of $\alpha$-CT in AOT/isooctane RM system can be accounted for the enhanced hydrophobicity and interactions between the enzymes and the micellar interfaces. ${ }^{30-32}$ In the present system stability of $\alpha$-CT may be due to the reduced repulsive interactions between the enzyme and the negatively charged polar heads of the surfactant.

\subsection{Influence of AOT on the water content, $w_{\mathrm{o}}$}

For the technological applications of the enzyme in low water content systems, sufficient studies have been made during the last two decades. Results of such studies will not only help to enhance the catalytic efficiency of enzymes but also lead enzymes to catalyse reactions which are impossible in water. Many enzymes have been studied in low water content systems including lipase, ${ }^{31,33-35}$ cutinase, ${ }^{36,37}$ lysozyme, ${ }^{38}$ peroxidase $^{39}$ reductase $^{40}$ and tyrosinase ${ }^{41}$ etc. Owing to wide applications of $\alpha$-CT, its superactivity in low water content AOT/isooctane/buffer RM system has been investigated so that its catalytic efficiency at lower $\mathrm{w}_{\mathrm{o}}$ values can be explored. Menger et al. have studied enzyme catalysis in water pools. ${ }^{42}$ Barbaric et al. have reported activity and concentration of $\alpha$-CT as the function of water pool content. ${ }^{23}$ Several enzymes show optimal activity in the range of $\mathrm{w}_{\mathrm{o}}$ from 8 to 13 . The entrapment of $\alpha$-CT into RMs forming an optically transparent solution, which has carried out by the injection technique. ${ }^{43,44}$ Here, an aqueous solution of the $\alpha$ CT has into a solution of the surfactant in organic solvent. The incorporation of the $\alpha$-CT into the water pool is almost instantaneous and only requires agitation for

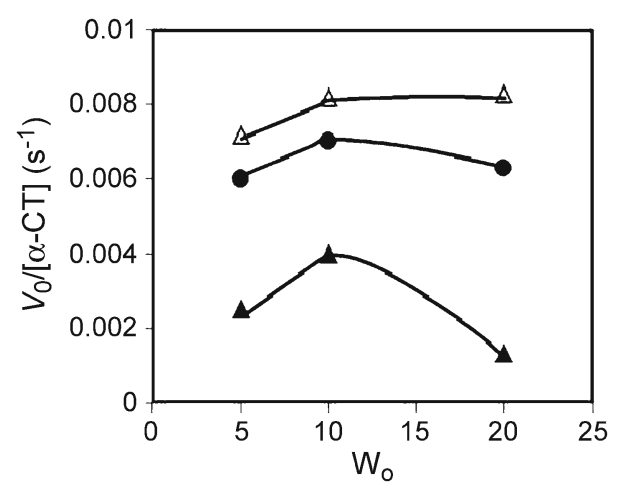

Figure 5. Effect of the water content, $\mathrm{w}_{\mathrm{o}}$, on the initial velocity per enzyme for the hydrolysis of PNPA in AOT/isooctane RMs. $\{[\mathrm{AOT}]=(\bullet) 5 \mathrm{mM} ;(\Delta) 15 \mathrm{mM} ;(\boldsymbol{\Delta})$ $25 \mathrm{mM}\},[\alpha-\mathrm{CT}]=13 \mu \mathrm{M},[\mathrm{PNPA}]=0.13 \mathrm{mM}$. Temp. $=$ $27^{\circ} \mathrm{C}, \mathrm{pH}=7.75$, [Tris $/ \mathrm{HCl}$ buffer $]=10 \mathrm{mM}$. 
a few seconds. This procedure is simple, quick and precisely controls the water content, $\mathrm{w}_{\mathrm{o}}$ of the resulting micellar solution. Hence, a dynamic exchange process between the aqueous core and the organic phase is considered to be responsible for the $\alpha$-CT solublization. Figure 5 shows maximal activity of $\alpha-\mathrm{CT}$ at $\mathrm{w}_{\mathrm{o}}=10$, which further reduced gradually up to $\mathrm{w}_{\mathrm{o}}=20$. This can be explained on the basis of water pool content in the RM system. Low $\mathrm{w}_{\mathrm{o}}$ probably causes decrease in the conformational flexibility of the proteins in RMs. ${ }^{45,46}$ In microemulsions $\alpha$-CT activity was measured at high water content i.e. from $\mathrm{w}_{\mathrm{o}}=31-36$ and better catalytic efficiency was observed in MEs as compared to RMs.

\subsection{Effect of mixed surfactant on enzymatic efficiency of $\alpha-C T$}

Sufficient evidences have been reported in our previous work ${ }^{25-27}$ regarding significant changes in enzymatic activity in single surfactant systems (cationic) but influence of mixed surfactant systems on $\alpha$-CT activity in reverse micelles is a new approach. Levinger et al. have studied the impact of mixed surfactants on probe molecule in RM. ${ }^{16}$ Important contribution was from Stjerndahl et al. ${ }^{47}$ the alkaline hydrolysis of the cationic species was strongly enhanced by micellization, whereas the nonionic species was virtually protected when residing in aggregates. The aggregation affected the two classes in opposite directions. Whereas micellization increased the hydrolysis rate for the cationic ester surfactant, it decreased the rate of ester cleavage for the nonionic surfactant.
Some additives are used to improve the capacities of the micellar systems with their ability to form inverted micelles as it is the case of mixed surfactants. The main purpose of the present work is to investigate the effect of mixed surfactants formation on the activity of $\alpha-\mathrm{CT}$ in AOT/buffer/isooctane/mixed surfactants (SB3-10, SB3-16 and TX-100) system (table 3). In AOT only, we found that $\alpha$-CT catalysed hydrolysis of PNPA showed $k_{\text {cat }}$ of $7.19 \times 10^{-2} \mathrm{~s}^{-1}$ and $K_{\mathrm{M}}$ of $1.05 \times 10^{-3} \mathrm{M}$. With the increasing concentration of AOT/SB3-10, $0.5 \mathrm{mM}$ to $2.5 \mathrm{mM}$, the $k_{\text {cat }}$ increases from $2.30 \times 10^{-2} \mathrm{~s}^{-1}$ to $16.7 \times 10^{-2} \mathrm{~s}^{-1}$, respectively and upon further increasing concentration of AOT/SB3-10 up to $5.0 \mathrm{mM}$ the $k_{\text {cat }}$ decreases to $8.90 \times$ $10^{-2} \mathrm{~s}^{-1}$. On the other hand, the $K_{\mathrm{M}}$ values in SB3-10 decreases from $0.5 \mathrm{mM}$ to $2.5 \mathrm{mM}$ and further increases up to $5.0 \mathrm{mM}$ of SB3-10 as presented in table 3. Similar trends are followed in the presence of AOT/SB3-16 and AOT/TX-100 i.e. increment was observed in $k_{\text {cat }}$ values from $0.5 \mathrm{mM}$ to $2.5 \mathrm{mM}$ which further reduced up to $5.0 \mathrm{mM}$. Whereas, $K_{\mathrm{M}}$ values falls up to $2.5 \mathrm{mM}$ and further rises up to $5.0 \mathrm{mM}$ (SB3-16) and $10 \mathrm{mM}$ (TX$100)$. The catalytic efficiency of $\alpha-\mathrm{CT}$ in AOT/SB310, AOT/SB3-16 and AOT/TX-100 was 2.48, 2.89 and 2.29 times higher than the free AOT, respectively.

For the assessment of catalytic efficiency of $\alpha-\mathrm{CT}$, the ratio of catalytic rate constant, $k_{\text {cat }}$ and Michaelis constant, $K_{\mathrm{M}}$ are plotted against surfactant concentration (figure 6). The bell shaped curves are obtained indicating the increase in catalytic efficiency, $k_{\text {cat }} / K_{\mathrm{M}}$ with increasing surfactant concentration up to $2.5 \mathrm{mM}$ and falls at higher concentration. SB3-10 and SB3-16 are zwitterionic surfactant and have unique properties to

Table 3. Effect of co-surfactant addition on the kinetics of $\alpha$-CT catalysed hydrolysis of PNPA in AOT/isooctane reverse micelles.

\begin{tabular}{lcccc}
\hline Co-surfactant & [Co-surfactant] $\mathrm{mM}$ & $10^{2} k_{\text {cat }}\left(\mathrm{s}^{-1}\right)$ & $10^{3} K_{\mathrm{M}}(\mathrm{M})$ & $k_{\text {cat }} / K_{\mathrm{M}}\left(\mathrm{M}^{-1} \mathrm{~s}^{-1}\right)$ \\
\hline AOT & 0 & $7.19 \pm 1.48$ & $1.05 \pm 0.03$ & 68.4 \\
AOT + SB3-10 & 0.5 & $2.30 \pm 0.06$ & $1.20 \pm 0.02$ & 19.1 \\
& 1.0 & $9.55 \pm 0.51$ & $1.16 \pm 0.02$ & 82.3 \\
& 2.5 & $16.7 \pm 7.76$ & $0.98 \pm 0.09$ & 170 \\
AOT + SB3-16 & 5.0 & $8.90 \pm 0.75$ & $1.10 \pm 0.03$ & 80.9 \\
& 0.5 & $4.59 \pm 0.43$ & $1.23 \pm 0.02$ & 37.3 \\
& 1.0 & $17.3 \pm 2.60$ & $1.10 \pm 0.03$ & 157 \\
AOT + TX-100 & 2.5 & $17.7 \pm 2.43$ & $0.89 \pm 0.04$ & 198 \\
& 5.0 & $13.5 \pm 2.50$ & $1.50 \pm 0.03$ & 90.0 \\
& 0.5 & $10.1 \pm 0.47$ & $1.30 \pm 0.05$ & 77.6 \\
& 1.0 & $13.7 \pm 2.32$ & $1.28 \pm 0.03$ & 107 \\
& 5.5 & $16.2 \pm 1.99$ & $1.03 \pm 0.20$ & 157 \\
& 10 & $14.7 \pm 3.23$ & $1.40 \pm 0.04$ & 105 \\
& 10 & $14.4 \pm 1.44$ & $1.51 \pm 0.10$ & 95.3
\end{tabular}

$[\alpha-\mathrm{CT}]=13 \mu \mathrm{M},[\mathrm{AOT}]=15 \mathrm{mM}, \mathrm{w}_{\mathrm{o}}=10,[$ Tris $/ \mathrm{HCl}$ buffer $]=10 \mathrm{mM}$, Temp. $=27^{\circ} \mathrm{C}$, $\mathrm{pH}=7.75$, $[\mathrm{PNPA}]=(0.065-0.52) \mathrm{mM}$ 


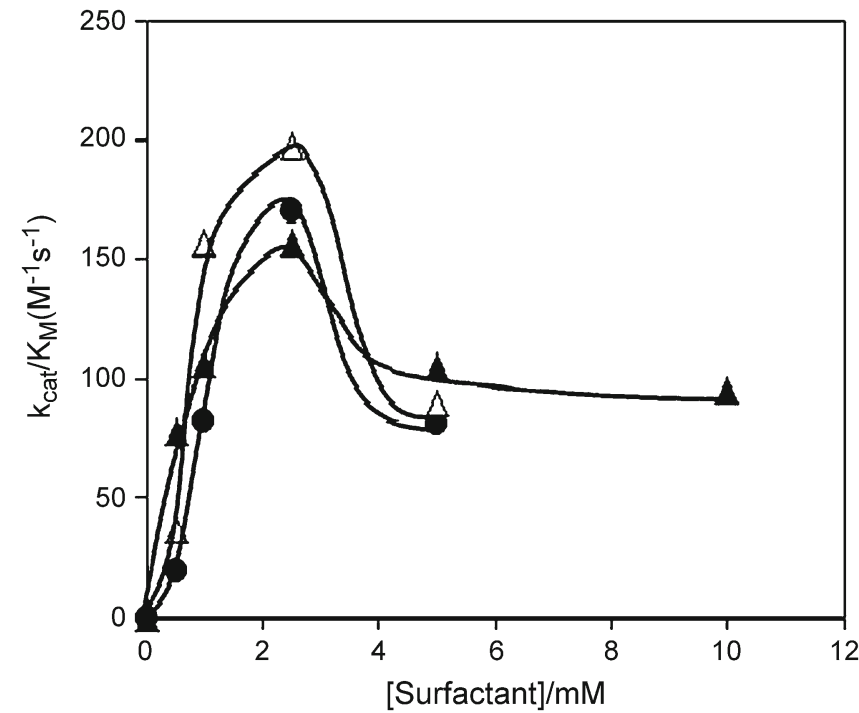

Figure 6. Effect of surfactant concentration on the $k_{\mathrm{cat}} / K_{\mathrm{M}}$.

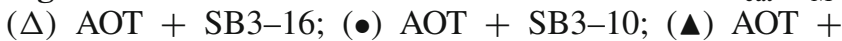
Triton-100. $[\alpha-\mathrm{CT}]=13 \mu \mathrm{M},[\mathrm{PNPA}]=(0.065-0.39) \mathrm{mM}$, $[\mathrm{AOT}]=15 \mathrm{mM}, \mathrm{w}_{\mathrm{o}}=10$.

solubilize membrane bound protein without denaturing them. Mixed surfactants addition modifies the interfacial properties increasing the water uptake, hence modifying the catalytic microenvironment. Effect of mixed surfactants also improves the aggregation and alters the enzyme structurally. When forming mixed aggregates with the surfactant the alcoholic product will decrease the head group repulsion, which will result in a decrease of the cmc. This can be expected to give an increase in the observed reaction rate because it increases the fraction of surfactant residing in the more reactive micellar pseudophase. Apart from that, the dilution of the surface charge of the micelles will result in decreased counter ion binding, which will have a negative effect on the reaction rate.

Table 4. Effect of chain length of zwitterionic surfactant on the enzymatic efficacy of $\alpha$-CT as a function of cosurfactant addition in AOT/isooctane reverse micellar media are showing the initial velocity $\left(V_{\mathrm{o}}\right)$ of $\alpha$-CT catalysed hydrolysis of PNPA at $\mathrm{pH}=7.75$. AOT $=15 \mathrm{mM}, \mathrm{w}_{\mathrm{o}}=10$, $[\alpha-\mathrm{CT}]=13 \mu \mathrm{M},[\mathrm{PNPA}]=0.13 \mathrm{mM}$.

\begin{tabular}{lcc}
\hline & \multicolumn{2}{c}{$V_{\mathrm{o}} \pm 0.02 \mu \mathrm{M} / \mathrm{s}$} \\
\cline { 2 - 3 }$[$ Co-surfactant] $\mathrm{mM}$ & SB3-10 & SB3-16 \\
\hline 0.5 & 0.121 & 0.126 \\
1.0 & 0.125 & 0.131 \\
2.5 & 0.163 & 0.166 \\
5.0 & 0.118 & 0.145 \\
\hline
\end{tabular}

Another hand, the addition of non-ionic surfactants TX-100 decreases the packing density of the anionic surfactant AOT, which may be favourable to increasing the dissociation degree of the AOT head groups and charging of the droplet. ${ }^{9}$ The above discussion shows that a quantitative treatment of the effects of aggregation on the $\alpha$-CT hydrolysis of each of the two surfactants in the mixture is not trivial (table 3). After the hydrolysis reaction is initiated, the system will contain several components, may affect the conditions in the micellar pseudophase in different, and sometimes competing, ways.

\subsection{Effect of chain length of mixed surfactant}

The effect of varying mixed surfactants chain length on $\alpha$-CT catalysed hydrolysis of PNPA was investigated at $\mathrm{pH}=7.75\left(\right.$ AOT $\left.=15 \mathrm{mM}, \mathrm{w}_{\mathrm{o}}=10\right)$ and results are summarized in table 4 . It can clearly inferred from the table 4, that with increase in the mixed surfactant chain length there is notable increase in initial velocity of enzyme. Comparative study proved that the initial velocities obtained at different concentration of mixed surfactant were higher for SB3-16. This can be accounted for the reason that when long chain mixed surfactants are applied there is hindrance of attractive interaction with reduced interfacial thickness at the micellar interface.

\section{Conclusions}

The present result shows the significant approach of $\alpha$-CT activity in AOT/isooctane RMs to varying concentration of AOT and addition of single/mixed surfactants. Informations obtained from the present study can enhance our understanding for enzymatic hydrolysis of carboxylate esters in low water content system. The size of water pool plays a very significant role on the aggregation behaviour of surfactant and enzymatic hydrolysis.

In summary, AOT/isooctane/mixed surfactants (SB3-10, SB3-16 and TX-100) RMs was more effective than AOT/isooctane RM system under same $\mathrm{pH}$ and temperature condition. Above results indicate that the effect of micellization on AOT/isooctane mixed surfactant media are may due to that the alcoholic product of reaction will decrease the head group repulsion and the dilution of the surface charge of the micelles will decreased counter ion binding, which will have a negative effect on the reaction rate. On the other hand particularly in RMs stability of $\alpha$-CT not only depends upon water content but also time after preparation. It can be 
concluded that enhancement in activity and stability of $\alpha$-CT along with the increase in the water pool size and the amount of AOT and mixed surfactant media.

\section{Acknowledgements}

Financial support from the Council of Scientific and Industrial Research, New Delhi (CSIR Project Ref. No. 01 (2143)/07/EMR-II) is gratefully acknowledged. Authors are also grateful to UGC SAP Project of Pt. Ravishankar Shukla University, Raipur.

\section{References}

1. Asano Y, Akita H and Nakamura K 2010 J. Mol. Catal. B: Enzym. 62108

2. Hedstrom L 2002 Chem. Rev. 1024501

3. Powers J C, Asgian J L, Ekici Z D and James K E 2002 Chem. Rev. 1024639

4. Dasgupta A, Das D and Das P K 2005 Biochimie 87 1111

5. Kandasamy R, Kennedy L J, Vidya C, Boopathy R and Sekaran G 2010 J. Mol. Catal. B: Enzym. 6258

6. Popescu D, Hoogenboom R, Keul H and Moeller M 2010 J. Mol. Catal. B: Enzym. 6281

7. Spreti N, Mancini M V, Germani R, Profio P D and Savelli G 2008 J. Mol. Catal. B: Enzym. 501

8. Falcone R D, Biasutti M A, Correa N M, Silber J J, Lissi E and Abuin E 2004 Langmuir 205732

9. Liu D, Ma J, Cheng H and Zhao Z 1998 Colloids Surf., A Physicochem. Eng. Aspects 135157

10. Biasutti M A, Abuin E B, Silber J J, Correa, N M and Lissi E A 2008 Adv. Colloid Interface Sci. 1361

11. Zaks A and Klibanov A M 1988 J. Biol. Chem. 2633194

12. Xie D, Xu D, Zhang L and Guo, H. 2005 J. Phys. Chem. B 1095259

13. Hasegawa M 2001 Langmuir 171426

14. Chen N, Fan J, Xiang J, Chen J and Liang Y 2006 Biochim. Biophys. Acta 17641029

15. Simon L, and Goodman J M 2010 J. Org. Chem. 751831

16. Corbeil E M, Riter R E and Levinger N E 2004 J. Phys. Chem. B 10810777

17. Viparelli P, Alfani F and Cantarella M 2003 J. Mol. Catal. B: Enzym. 21175

18. Viparelli P, Alfani F and Cantarella M $2001 \mathrm{~J}$. Mol. Catal. B: Enzym. 151

19. Carvalho C M L and Cabral J M S 2000 Biochimie 82 1063

20. Alves J R S, Fonseca L P, Ramalho M T and Cabral J M S 2003 Biochem. Eng. J. 1581
21. Freeman K S, Tang T T, Shah R D E, Kiserow D J and McGown L B 2000 J. Phys. Chem. B 1049312

22. Martinek K, Levashov A V, Klyachko N L, Pantin V I, Kabanov A V and Berezin I V 1981 Biochim. Biophys. Acta 657277

23. Barbaric S and Luisi P L 1981 J. Am. Chem. Soc. 103 4239

24. Verma S K and Ghosh K K 2010 Colloids Surf., A Physicochem. Eng. Aspects $\mathbf{3 6 8} 154$

25. Verma S K and Ghosh K K 2010 Indian J. Chem. Sect. A 491041

26. Ghosh K K and Verma S K 2009 Int. J. Chem. Kinet. 41 377

27. Ghosh K K and Verma S K 2008 Indian J. Biochem. Biophy. 45350

28. Yu Z J, Zhou N F and Neuman R D 1992 Langmuir 8 1885

29. Aguilar L F, Abuin E and Lissi E 2001 Arch. Biochem. Biophys. 388231

30. Serralheiro M L M and Cabral J M S 1999 J. Mol. Catal. B: Enzym. 7191

31. Stamatis H, Xenakis A and Kolisis F N 1999 Biotechnol. Adv. 17293

32. Otero C, Rua M L and Robledo L 1995 FEBS Lett. 360 202

33. Zoumpanioti M, Stamatis H and Xenakis A 2010 Biotechnol. Adv. 28395

34. Nagayama K, Matsu-ura S, Doi T and Imai M 1998 J. Mol. Catal. B: Enzym. 425

35. Debnath S, Dasgupta A, Mitra R N and Das P K 2006 Langmuir 228732

36. Brissos V, Melo E P, Martinho J M G and Cabral J M S 2008 Biochim. Biophys. Acta $\mathbf{1 7 8 4} 1326$

37. Melo E P, Baptista R P and Cabral J M S 2003 J. Mol. Catal. B: Enzym. 22299

38. Grandi C, Smith R E and Luisi P L 1981 J. Biol. Chem. 256837

39. Roy S, Dasgupta A and Das P K 2006 Langmuir 224567

40. Zhu H, Fan Y X, Shi N and Zhou J M 1999 Arch. Biochem. Biophys. 36861

41. Yang Z, Deng J and Chen L F 2007 J. Mol. Catal. B: Enzym. 4779

42. Menger F M and Yamada K 1979 J. Am. Chem. Soc. 101 6731

43. Martinek K, Levashov A V, Klyachko N L and Berezin I V 1977 Dokl. Akad. Nauk. SSSR 236920

44. Martinek K and Berezin I V 1977 Solid-Phase Biochem. 2343

45. Bhattacharya S and Snehalatha K 1997 Langmuir 13378

46. Miyake Y 1996 Colloids Surf., A: Physicochem. Eng. Aspects 109255

47. Lundberg D, Stjerndahl M and Holmberg K 2005 Langmuir 218658 